\title{
Biological and synthetic approaches to inhibiting nitrification in non-tilled Mediterranean soils
}

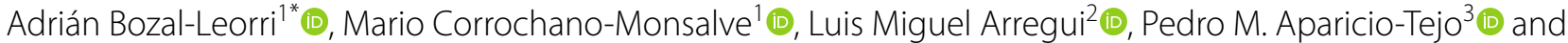 \\ Carmen González-Murua' [D
}

\begin{abstract}
Background: The increasing demand for food production has led to a tenfold increase in nitrogen $(\mathrm{N})$ fertilizer use since the Green Revolution. Nowadays, agricultural soils have been turned into high-nitrifying environments that increase N pollution. To decrease N losses, synthetic nitrification inhibitors (SNIs) such as 3,4-dimethylpyrazole phosphate (DMPP) have been developed. However, SNIs are not widely adopted by farmers due to their biologically limited stability and soil mobility. On the other hand, allelopathic substances from root exudates from crops such as sorghum are known for their activity as biological nitrification inhibitors (BNIs). These substances are released directly into the rhizosphere. Nevertheless, BNI exudation could be modified or even suppressed if crop development is affected. In this work, we compare the performance of biological (sorghum crop) and synthetic (DMPP) nitrification inhibitors in field conditions.
\end{abstract}

Results: Sorghum crop BNIs and DMPP prevented an increase in the abundance of ammonia-oxidizing bacteria (AOB) without affecting the total bacterial abundance. Both nitrification inhibitors maintained similar soil $\mathrm{NH}_{4}^{+}$content, but at 30 days post-fertilization (DPF), the sorghum BNIs resulted in higher soil $\mathrm{NO}_{3}{ }^{-}$content than DMPP. Even so, these inhibitors managed to reduce $64 \%$ and $96 \%$, respectively, of the $\mathrm{NO}_{3}{ }^{-}-\mathrm{N} \mathrm{NH}_{4}{ }^{+}-\mathrm{N}$ ratio compared to the control treatment. Similar to soil mineral $\mathrm{N}$, there were no differences in leaf $\delta^{15} \mathrm{~N}$ values between the two nitrification inhibitors, yet at $30 \mathrm{DPF}, \delta^{15} \mathrm{~N}$ values from sorghum BNI were more positive than those of DMPP. $\mathrm{N}_{2} \mathrm{O}$ emissions from DMPP-treated soil were low throughout the experiment. Nevertheless, while sorghum BNIs also maintained low $\mathrm{N}_{2} \mathrm{O}$ emissions, they were associated with a substantial $\mathrm{N}_{2} \mathrm{O}$ emission peak at 3 DPF that lasted until 7 DPF.

Conclusions: Our results indicate that while sorghum root exudates can reduce nitrification in field soil, even at the same efficiency as DMPP for a certain amount of time, they are not able to prevent the $\mathrm{N}$ pollution derived from $\mathrm{N}$ fertilization as DMPP does during the entire experiment.

Keywords: Sorghum, DMPP, amoA gene, Soil mineral nitrogen, $\delta^{15} \mathrm{~N}$, Nitrous oxide emissions, No-till farming

\section{Background}

Sorghum (Sorghum bicolor L. Moench) is a widely cultivated cereal, being the fifth most important after wheat, maize, rice and barley [1]. The heat tolerance and drought

\footnotetext{
*Correspondence: adrian.bozal@ehu.eus

${ }^{1}$ Department of Plant Biology and Ecology, University of the Basque

Country (UPV/EHU), Apdo. 644, 48080 Bilbao, Spain

Full list of author information is available at the end of the article
}

resistance that it possesses has made it well adapted to semiarid regions [2, 3]. While Africa and India cultivate sorghum for human food, which accounts for $40 \%$ of world sorghum production, countries in North America and Europe use sorghum for biomass production and livestock feed $[4,5]$. However, sorghum is becoming relevant for industrialized countries because its grain is safe for celiac and gluten-intolerant people [6]. Therefore, it can meet the growing demand for gluten-free foods and 
beverages from consumers who cannot eat products containing wheat, barley or rye [7]. Besides becoming a safe food product, sorghum is also known for the allelopathy of its root exudates. The molecules that have been characterized in sorghum exudates are sorgoleone [8] and 3,4-hydroxyphenyl propionate (MHPP) [9]. Sorgoleone was initially used for its substantial weed-suppressing capability [10], but later its potential as a biological nitrification inhibitor (BNI) was discovered. More than $80 \%$ of the hydrophobic component of sorghum-exuded BNIs is sorgoleone [11], while MHPP comprises the hydrophilic component. Both molecules can reduce nitrification in soil [12, 13]. Subbarao et al. [14] characterize the BNI activity from MHPP and sorgoleone in the soil. Once these molecules are released from sorghum roots, their nitrification inhibitory action seems to be relatively stable over a pH range of 3.0 to 9.0. This is in contrast to BNIs release from other plants, such as Brachiaria humidicola, whose molecules are reported to have a total loss of inhibitory function at $\mathrm{pH} \geq 8.0$. Moreover, the inhibitory effect on soil nitrification of MHPP and sorgoleone appears to be stable in the temperature range of 20 to $30{ }^{\circ} \mathrm{C}$.

The use of crops that produce BNIs could be the first step towards a low-nitrifying agronomic environment in agricultural systems [15]. The tenfold increase in the use of nitrogen (N) fertilizers since the Green Revolution [16] has greatly augmented food production, but it has turned agricultural soils into high-nitrifying environments with significant environmental costs [17]. Nitrification is the biological transformation of $\mathrm{N}$ in the form of ammonium $\left(\mathrm{NH}_{4}{ }^{+}\right)$into oxidized $\mathrm{N}$. Chemolithoautotrophic ammonia-oxidizing bacteria (AOB) and archaea (AOA) oxidize $\mathrm{NH}_{4}{ }^{+}$to hydroxylamine $\left(\mathrm{NH}_{2} \mathrm{OH}\right)$ through the ammonium monooxygenase enzyme (AMO) encoded by the amoA gene [18]. $\mathrm{NH}_{2} \mathrm{OH}$ is converted to nitrite $\left(\mathrm{NO}_{2}{ }^{-}\right)$and then, nitrite-oxidizing bacteria (NOB) oxidize it to nitrate $\left(\mathrm{NO}_{3}{ }^{-}\right)$[19]. MHPP blocks the AMO enzyme, while sorgoleone blocks both the AMO and the HAO enzyme [14]. The chemical structure of sorgoleone, which has a hydroquinone head and a fatty acid tail with a terminal double bond, has the potential to disrupt the electron flow between AMO and HAO enzymes and hence the nitrification activity [20]. Following with the final product of nitrification, as $\mathrm{NO}_{3}{ }^{-}$is a negatively charged anion, it is repelled by negatively charged soil colloids and is thus lost through leaching, causing eutrophication and contamination of groundwater supplies [21]. Furthermore, in anoxic conditions, $\mathrm{NO}_{3}{ }^{-}$is the substrate for a denitrification process that releases $\mathrm{N}$ gases such as nitrous oxide $\left(\mathrm{N}_{2} \mathrm{O}\right)$ [22]. The global warming potential (GWP) of $\mathrm{N}_{2} \mathrm{O}$ is 265 to 298 times higher than $\mathrm{CO}_{2}$ over a 100-year time horizon [23]. Therefore, it is necessary to reduce the pollution originating from the application of $\mathrm{N}$ fertilizer, particularly as its use is expected to double by 2050 [24].

Synthetic nitrification inhibitors (SNIs) have been developed to decrease $\mathrm{N}$ losses by suppressing soilnitrifier activity. The dimethylpyrazole-based SNI DMPP (3,4-dimethylpyrazole phosphate) is able to reduce $\mathrm{AOB}$ abundance, delaying the oxidation of $\mathrm{NH}_{4}{ }^{+}$while diminishing $\mathrm{N}_{2} \mathrm{O}$ emissions $[25,26]$. However, the use of SNIs is not widely adopted by farmers [27]. The inhibitory effect does not last more than a few weeks, they have biologically limited stability, and SNI mobility could prevent these molecules from acting on the sites of nitrification $[15,28]$. On the other hand, BNIs are exuded directly into the rhizosphere, which is the main site of nitrification due to the great abundance of AOB and AOA [29]. Moreover, sorghum BNIs are known for being stable across a wide range of soil $\mathrm{pH}$ and temperature [14]. In addition, BNIs from sorghum can be released until close to physiological maturity of the crop [14], which would ensure the presence of nitrification inhibitors during all the stages of crop development. Nevertheless, BNI exudation is related to the physiological state and development of the plant [30], so biotic or abiotic stresses that affect crop growth might modify the rate of BNI exudation or even prevent its release.

Sorghum allelopathy is highlighted in the framework of sustainable agriculture and its use could drive cultivation systems towards environmentally friendly agronomic practices that allow us to meet global food demand while reducing the loss of reactive $\mathrm{N}$ into the environment. For this reason, the aim of this work was to compare under field conditions the performance of biological and synthetic nitrification inhibitors in retaining $\mathrm{NH}_{4}{ }^{+}$in soil for longer periods and reducing $\mathrm{AOB}$ growth and its effect on $\mathrm{N}_{2} \mathrm{O}$ emissions.

\section{Methods \\ Experimental design}

This work was conducted in Pamplona, northern Spain $\left(42^{\circ} 47^{\prime} \mathrm{N}, 1^{\circ} 37^{\prime} \mathrm{W}, 450 \mathrm{~m}\right.$ above sea level), from May to October 2019. Table 1 describes the soil characteristics of the upper horizon. Daily precipitation and mean temperatures are shown in Additional file 1: Fig. S1. Sorghum (Sorghum bicolor L. var. PR88P68 Pioneer Corteva Agriscience $^{\circledR}$ ) was sown under no-tillage at a rate of $15 \mathrm{~kg}$ seeds ha ${ }^{-1}$ on 15th May 2019 after a previous hairy vetch (Vicia villosa L.) winter cover crop. The vetch was terminated with $1.5 \mathrm{~kg} \mathrm{ha}^{-1}$ dose of glyphosate on 29th April, rate that is routinely applied in no-till system from this region, and left on the soil surface. This experiment consisted of three randomized $\mathrm{N}$ treatments with four replications $(5 \mathrm{~m} \times 5 \mathrm{~m}$ plots). The $\mathrm{N}$ treatments 





were (1) sorghum without fertilizer (Control); (2) sorghum fertilized with ammonium sulfate (AS) and (3) sorghum fertilized with ammonium sulfate combined with DMPP $(\mathrm{AS}+\mathrm{D})$. The fertilizer application rate was $150 \mathrm{~kg} \mathrm{~N} \mathrm{ha}{ }^{-1}$ in the form of ammonium sulfate $21 \%$, with the fertilizer hand broadcast on 7th July 2019 in a single application at the beginning of stem elongation (Z30) according to the Zadoks scale [31]. Fertilizer combined with DMPP inhibitor was provided by EuroChem Agro Iberia S.L. The DMPP rate was $0.8 \%$ of the $\mathrm{NH}_{4}{ }^{+}-\mathrm{N}$ applied with the fertilizer. As the purpose of this experiment was only to measure the effects of the sorghum crop on $\mathrm{N}$ losses, sorghum was not harvested and it was terminated on 14th October 2019 and left on the soil surface according to usual management practices.

\section{Plant analysis}

The $\mathrm{N}$ isotopic composition in sorghum leaves was determined with an elemental analyser (FlashEA1112 ThermoFinnigan) coupled to a mass spectrometer (DELTA ${ }^{\text {plus }}$ Finnigan MAT) in the Unidade de Técnicas Instrumentais de Análise, Servizos de Apoio á Investigación (SAI), Universidade da Coruña. To do so, one sorghum plant per plot was taken randomly at $10,20,30$, and 60 days post-fertilization and dried at $80{ }^{\circ} \mathrm{C}$ in a circulation oven for $72 \mathrm{~h}$ until a constant dry weight was reached. Later, dry plants were ground with a ball miller (Retsch MM 500) at a frequency of $27 \mathrm{~s}^{-1}$ for $2 \mathrm{~min}$. The values of the isotopic ratio of $100 \mathrm{mg}$ of ground material were expressed as $\delta^{15} \mathrm{~N}$, in parts per thousand (\%o) relative to atmospheric $\mathrm{N}_{2}$. The isotope composition values $\delta$ (\%) were obtained with the following equation:

$$
\delta_{\text {sample }}(\%)=\left(\left(R_{\text {sample }}-R_{\text {standard }}\right) / R_{\text {standard }}\right) \times 1000,
$$

where $R_{\text {sample }}$ is the ${ }^{15} \mathrm{~N} /{ }^{14} \mathrm{~N}$ ratio of the plant sample and $R_{\text {standard }}$ is the ${ }^{15} \mathrm{~N} /{ }^{14} \mathrm{~N}$ ratio of the atmospheric $\mathrm{N}_{2}$.

\section{Soil analysis}

Soil $\mathrm{N}_{2} \mathrm{O}$ emissions were measured using the closed chamber method [36]. Gas samples were taken over 60 days post-fertilization at decreasing sampling frequency from three times per week over 2 weeks to twice per week in the subsequent 2 weeks and, finally, once per week until the end of measuring time. $\mathrm{N}_{2} \mathrm{O}$ samples were measured as detailed in [37].

Soil mineral $\mathrm{N}$ was determined based on the soil $\mathrm{NH}_{4}{ }^{+}$ and $\mathrm{NO}_{3}{ }^{-}$contents. Three soil subsamples $(3 \mathrm{~cm}$ diameter $\times 0.3 \mathrm{~m}$ depth) per plot were taken the day before the treatment application, and later at 10, 20, 30 and 60 days post-fertilization. Then, soil subsamples were homogenized with rocks and roots being removed. The
$\mathrm{NH}_{4}{ }^{+}$and $\mathrm{NO}_{3}{ }^{-}$contents were determined as described in [37]. Each day of soil and/or gas measurement two additional soil subsamples $(3 \mathrm{~cm}$ diameter $\times 0.3 \mathrm{~m}$ depth) were taken randomly from the field to determine soil water content. After removing rocks and roots, they were placed into a circulation oven at $80^{\circ} \mathrm{C}$ for $72 \mathrm{~h}$ until a constant dry weight was reached. Following [38], soil water content was described as the percentage of waterfilled pore space (WFPS):

$$
\begin{aligned}
\text { WFPS }= & (\text { soil gravimetric water content } \times \text { bulk density }) \\
& \times(1-(\text { bulk density } / \text { particle density }))^{-1},
\end{aligned}
$$

where $2.65 \mathrm{Mg} \mathrm{m}^{-3}$ was used as particle density. The density of the bulk soil was measured at the beginning of the experiment resulting in $1.0 \mathrm{Mg} \mathrm{m}^{-3}$.

Soil samples from mineral $\mathrm{N}$ determinations at 20 days post-fertilization were used to quantify the abundance of total bacteria (16s $r R N A$ ), and nitrifying (bacterial amoA) and denitrifying (nirK) populations. Quantification was done using quantitative polymerase chain reaction (qPCR) in a StepOne PlusTM Real-Time PCR System. Soil DNA isolation and gene amplification were carried out as explained in [39].

\section{Statistical analysis}

Data obtained in this experiment were statistically analysed with one-way ANOVA followed by Duncan's multiple range tests for separation of means between treatments using SPSS statistical software (IBM Corp. Released 2016. IBM SPSS Statistics for Windows, Version 24.0. Armonk, NY: IBM Corp). Significant differences are expressed at $p<0.05$.

\section{Results}

Fertilizer treatments did not have any effect on total bacterial abundance (Fig. 1a). Based on the $16 S$ rRNA gene copy number, bacterial abundance ranged from $1.00 \cdot 10^{9}$ to $1.10 \cdot 10^{9}$. Nitrifying bacteria were also not affected by $\mathrm{N}$ treatments, having an abundance of between 9.31.10 and $1.01 \cdot 10^{7}$ amoA gene copy numbers $\mathrm{g}^{-1}$ dry soil (Fig. 1b). Alike AOB, denitrifying microorganisms neither were affected by addition of fertilizer. They showed an abundance that varied from $7.31 \cdot 10^{5}$ to $8.12 \cdot 10^{5}$ nirK gene copy numbers $\mathrm{g}^{-1}$ dry soil (Fig. 1c).

After fertilizer application, the soil $\mathrm{NH}_{4}{ }^{+}$content increased in $\mathrm{AS}$ and $\mathrm{AS}+\mathrm{D}$ treatments maintaining higher values during the first 30 days post-fertilization (DPF) (Fig. 2a). At $30 \mathrm{DPF}$, the soil $\mathrm{NH}_{4}^{+}$content of fertilized treatments decreased to levels that were similar to the control treatment. However, it was observed that 

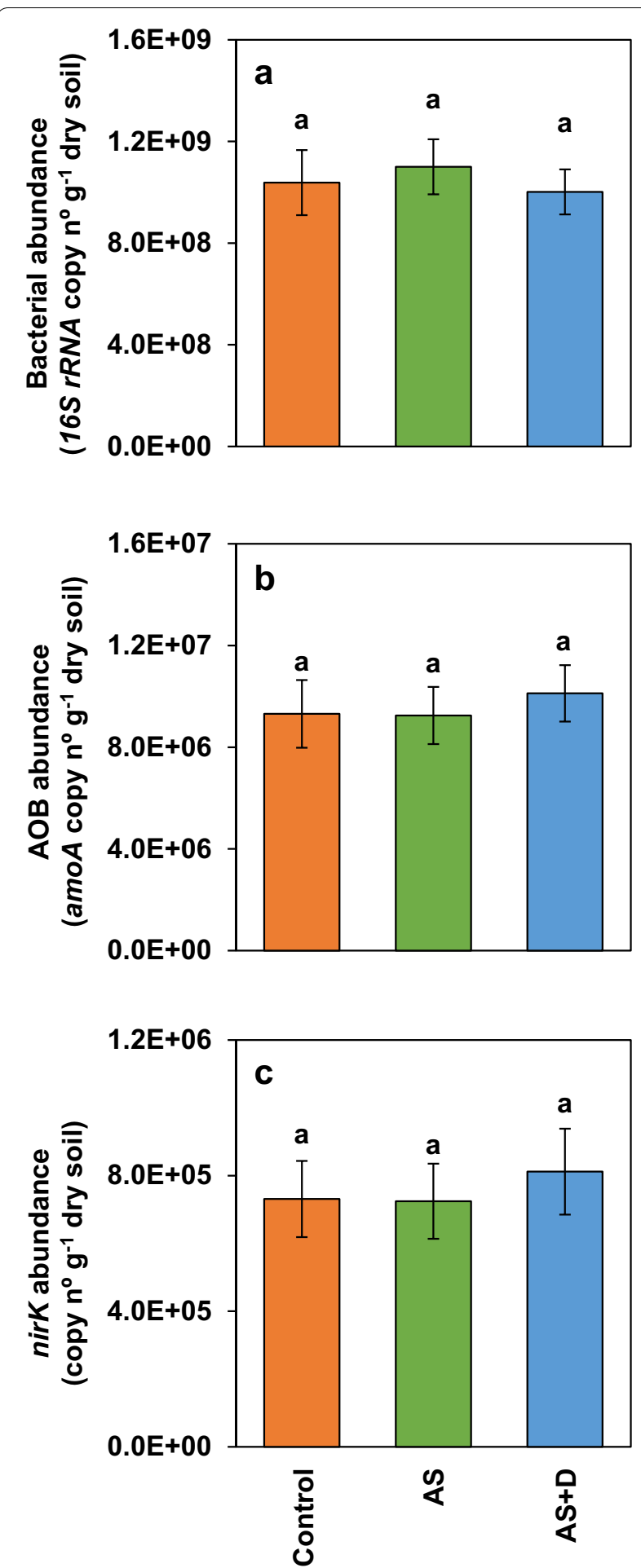

Fig. 1 Abundance of total bacteria (a), ammonia-oxidizing bacteria (AOB) (b) and the nirk gene (c) at 20 days post-fertilization (DPF). Control= sorghum without fertilization; $A S=$ sorghum fertilized with ammonium sulfate; $A S+D=$ sorghum fertilized with ammonium sulfate + DMPP. Different letters indicate significant differences using the Duncan test $(p<0.05 ; n=4)$ the soil $\mathrm{NH}_{4}{ }^{+}$content from the AS and AS $+\mathrm{D}$ treatments increased at $60 \mathrm{DPF}$, which might have been a consequence of mineralization. On the other hand, the AS treatment showed the highest soil $\mathrm{NO}_{3}{ }^{-}$content during the 60 days of measurement (Fig. 2b). Although the $\mathrm{AS}+\mathrm{D}$ treatment showed constant soil $\mathrm{NO}_{3}{ }^{-}$content during the first $20 \mathrm{DPF}$, it was able to diminish its formation to levels of unfertilized treatment until 60 DPF. Control treatment also showed low soil $\mathrm{NO}_{3}{ }^{-}$ content. Indeed, the highest $\mathrm{NO}_{3}{ }^{-}-\mathrm{N} / \mathrm{NH}_{4}{ }^{+}-\mathrm{N}$ ratio throughout the experiment was observed in the control treatment (Fig. 2c). The AS and AS + D treatments had equally low ratios during the first 20 DPF because there were no differences between them in terms of soil $\mathrm{NH}_{4}{ }^{+}$and $\mathrm{NO}_{3}{ }^{-}$content. Nevertheless, because the AS treatment did not decrease soil $\mathrm{NO}_{3}{ }^{-}$levels at $30 \mathrm{DPF}$, the $\mathrm{NO}_{3}{ }^{-}-\mathrm{N} / \mathrm{NH}_{4}{ }^{+}-\mathrm{N}$ ratio showed a sixfold increase compared to the AS + D treatment. Still, at $30 \mathrm{DPF}$ both treatments were able to reduce the $\mathrm{NO}_{3}{ }^{-}-\mathrm{N} / \mathrm{NH}_{4}{ }^{+}-\mathrm{N}$ ratio in AS and AS + D by $64 \%$ and $96 \%$, respectively, compared to the control treatment.

Sorghum leaves from the control treatment showed the least negative $\delta^{15} \mathrm{~N}$ values (Fig. 3a). The similarity in leaf $\delta^{15} \mathrm{~N}$ values between the AS and AS $+\mathrm{D}$ treatments until 20 DPF indicated no effect from DMPP up to this point. However, at $30 \mathrm{DPF}$, both fertilizer treatments showed an increase in $\delta^{15} \mathrm{~N}$ values that was greater in the AS treatment than the AS $+\mathrm{D}$ treatment, and the same $\delta^{15} \mathrm{~N}$ values were maintained until $60 \mathrm{DPF}$. As expected, the unfertilized treatment possessed the lowest leaf $\mathrm{N}$ content (Fig. 3b). Fertilized treatments showed higher $\mathrm{N}$ contents that declined throughout the experiment until they reached similar $\mathrm{N}$ values to the control treatment at $60 \mathrm{DPF}$. In this case, there were no differences between the AS and AS $+\mathrm{D}$ treatments.

The treatment fertilized with AS showed a substantial $\mathrm{N}_{2} \mathrm{O}$ emission peak at $3 \mathrm{DPF}$ with an emission of $38.7 \mathrm{~g} \mathrm{~N}_{2} \mathrm{O}-\mathrm{N}$ ha $^{-1} \mathrm{~d}^{-1}$ (Fig. 4a). Nevertheless, the peak was quickly reduced from 7 DPF, with $\mathrm{N}_{2} \mathrm{O}$ emissions in the AS treatment maintained between 3.79 and $0.74 \mathrm{~g} \mathrm{~N}_{2} \mathrm{O}-\mathrm{N} \mathrm{ha}^{-1} \mathrm{~d}^{-1}$. In contrast, the $\mathrm{N}_{2} \mathrm{O}$ emissions from the control and AS $+\mathrm{D}$ treatments were both low throughout the experiment, ranging from 4.23 to $0.67 \mathrm{~g} \mathrm{~N}_{2} \mathrm{O}-\mathrm{N} \mathrm{ha}^{-1} \mathrm{~d}^{-1}$ for the control treatment and from 4.01 to $0.31 \mathrm{~g} \mathrm{~N}_{2} \mathrm{O}-\mathrm{N} \mathrm{ha}{ }^{-1} \mathrm{~d}^{-1}$ for the $\mathrm{AS}+\mathrm{D}$ treatment. Although $\mathrm{N}_{2} \mathrm{O}$ emissions from AS treatment were reduced to levels similar to the control and AS $+\mathrm{D}$ treatments, it had the highest total cumulative $\mathrm{N}_{2} \mathrm{O}$ emissions due to the short emission peak (Fig. 4b). There were no differences between control and AS +D treatments in total cumulative $\mathrm{N}_{2} \mathrm{O}$ emissions, with reductions of $54 \%$ and $59 \%$, respectively, compared to the AS treatment. 


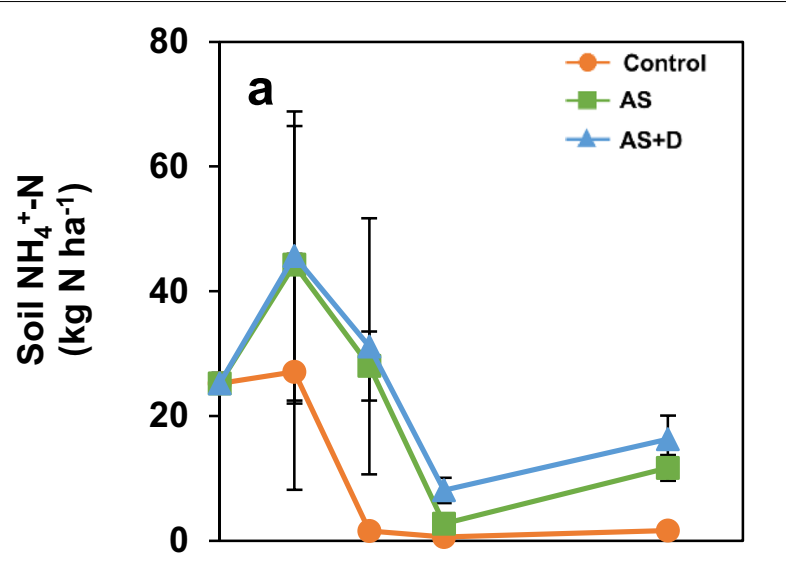

\begin{tabular}{ccccc}
\hline & 10 & 20 & 30 & 60 \\
\hline Control & $\mathrm{a}$ & $\mathrm{b}$ & $\mathrm{b}$ & $\mathrm{b}$ \\
AS & $\mathrm{a}$ & $\mathrm{a}$ & $\mathrm{b}$ & $\mathrm{a}$ \\
AS+D & $\mathrm{a}$ & $\mathrm{a}$ & $\mathrm{a}$ & $\mathrm{a}$ \\
\hline
\end{tabular}

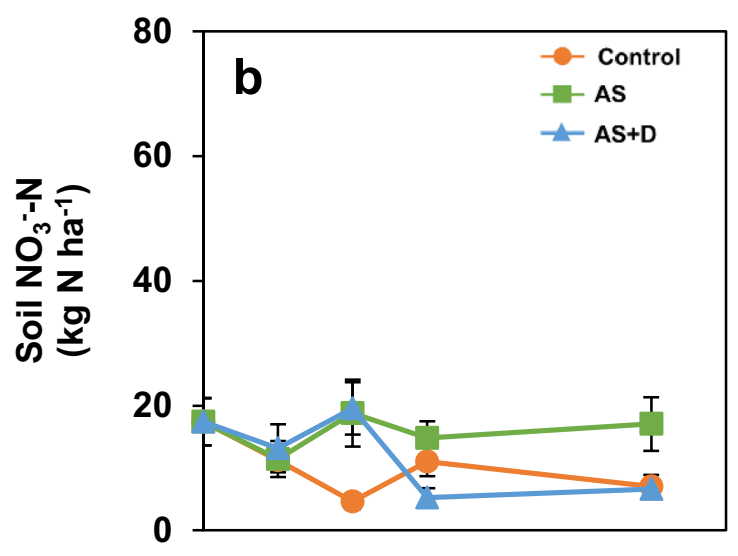

\begin{tabular}{ccccc}
\hline & 10 & 20 & 30 & 60 \\
\hline Control & $a$ & $b$ & $a b$ & $b$
\end{tabular}

\begin{tabular}{ccccc} 
AS & $a$ & $a$ & $a$ & $a$ \\
AS+D & $a$ & $a$ & $b$ & $b$ \\
\hline
\end{tabular}

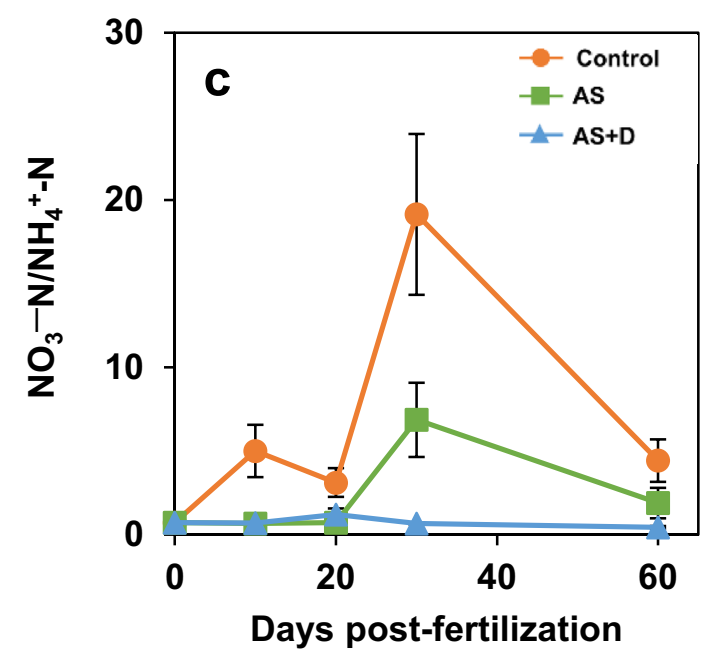

\begin{tabular}{ccccc}
\hline & 10 & 20 & 30 & 60 \\
\hline Control & $\mathrm{a}$ & $\mathrm{a}$ & $\mathrm{a}$ & $\mathrm{a}$ \\
AS & $\mathrm{b}$ & $\mathrm{b}$ & $\mathrm{b}$ & $\mathrm{ab}$ \\
AS+D & $\mathrm{b}$ & $\mathrm{b}$ & $\mathrm{c}$ & $\mathrm{b}$ \\
\hline
\end{tabular}

Fig. 2 Soil mineral nitrogen evolution over 60 days post-fertilization in the form of $\mathrm{NH}_{4}^{+}$(a), $\mathrm{NO}_{3}^{-}$(b) and the $\mathrm{NO}^{-}-\mathrm{N} / \mathrm{NH}^{+}{ }^{-}-\mathrm{N}$ ratio $(\mathbf{c})$. Control = sorghum without fertilization; $A S=$ sorghum fertilized with ammonium sulfate; $A S+D=$ sorghum fertilized with ammonium sulfate+DMPP. Different letters indicate significant differences using the Duncan test $(p<0.05 ; n=4)$

\section{Discussion}

During the last few decades, root exudates from sorghum have been well studied due to the presence of allelopathic substances [40]. Lately, investigations have focused on their ability to inhibit the nitrification pathway. There are several greenhouse and microcosm studies where molecules such as sorgoleone and MHPP have been characterized and their potential as BNIs investigated $[8,9,12$, 


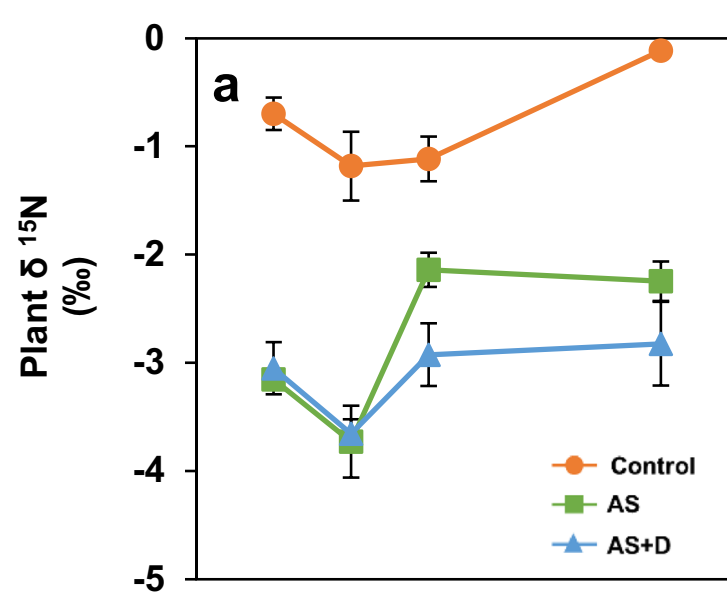

\begin{tabular}{ccccc}
\hline & 10 & 20 & 30 & 60 \\
\hline Control & $\mathrm{a}$ & $\mathrm{a}$ & $\mathrm{a}$ & $\mathrm{a}$ \\
AS & $\mathrm{b}$ & $\mathrm{b}$ & $\mathrm{b}$ & $\mathrm{b}$ \\
AS+D & $\mathrm{b}$ & $\mathrm{b}$ & $\mathrm{c}$ & $\mathrm{b}$ \\
\hline
\end{tabular}

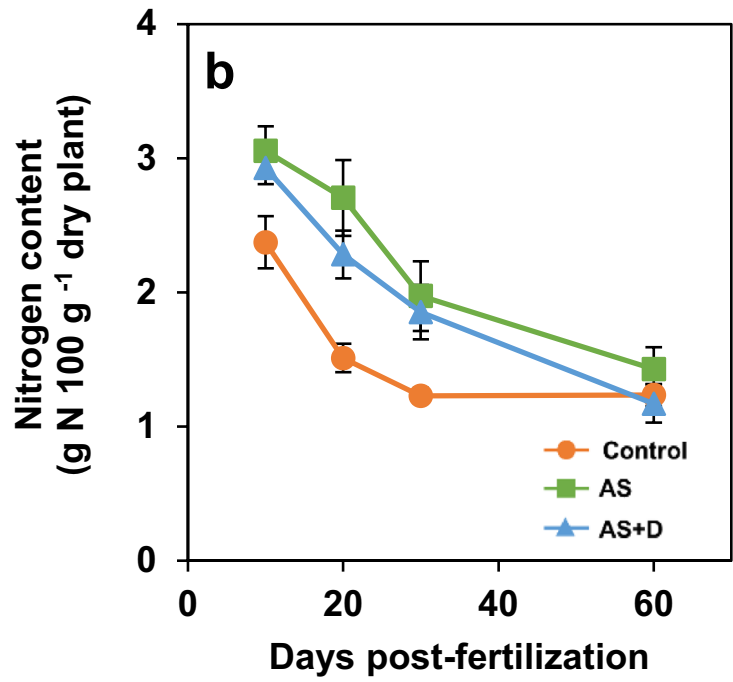

\begin{tabular}{ccccc}
\hline & 10 & 20 & 30 & 60 \\
\hline Control & $\mathrm{b}$ & $\mathrm{b}$ & $\mathrm{b}$ & $\mathrm{a}$ \\
AS & $\mathrm{a}$ & $\mathrm{a}$ & $\mathrm{a}$ & $\mathrm{a}$ \\
AS+D & $\mathrm{a}$ & $\mathrm{a}$ & $\mathrm{a}$ & $\mathrm{a}$ \\
\hline
\end{tabular}

Fig. 3 Determination of $\delta^{15} \mathrm{~N}(\mathbf{a})$ and nitrogen content $(\mathbf{b})$ in sorghum leaves. Control=sorghum without fertilization; $A S=$ sorghum fertilized with ammonium sulfate; $A S+D=$ sorghum fertilized with ammonium sulfate + DMPP. Different letters indicate significant differences using the Duncan test $(p<0.05 ; n=4)$

14]. One of the main aspects to consider in the attempt to improve agricultural sustainability is whether these substances could have a negative effect on soil health. Encouragingly, while MHPP molecules reduce AOB abundance, they do not exert a general negative impact on the soil bacterial community, as indicated by maintenance of $16 S$ rRNA gene abundance in microcosm experiments [12]. In the same manner, no effects on total bacterial abundance have been observed in soil from potgrown sorghum that release different quantities of sorgoleone [13]. Here, we corroborate that sorghum plants do not alter total bacterial abundance under field conditions (Fig. 1a). This is a confirmation that both sorghum root exudates and the synthetic nitrification inhibitor (SNI) DMPP do not produce general deleterious effects because
DMPP also had no effect on $16 S$ rRNA abundance, as reported here (Fig. 1a) and in several other studies [41, 42]. Nevertheless, previous work with DMP-based nitrification inhibitors and with sorgoleone has shown that there are some shifts in non-target bacterial abundance, even when the total bacterial abundance is not altered, with SNIs associated with decreases in bacterial diversity [43] and BNIs associated with changes in bacterial networks (BNIs) [44]. These studies are still preliminary, so further work should expand these analyses to determine exactly what effects are exerted by these compounds on the soil microbiota.

Fertilizer stimulates root development, changes the soil $\mathrm{pH}$ and increases the availability of nutrients for microorganisms and, consequently, the soil bacterial consortia 

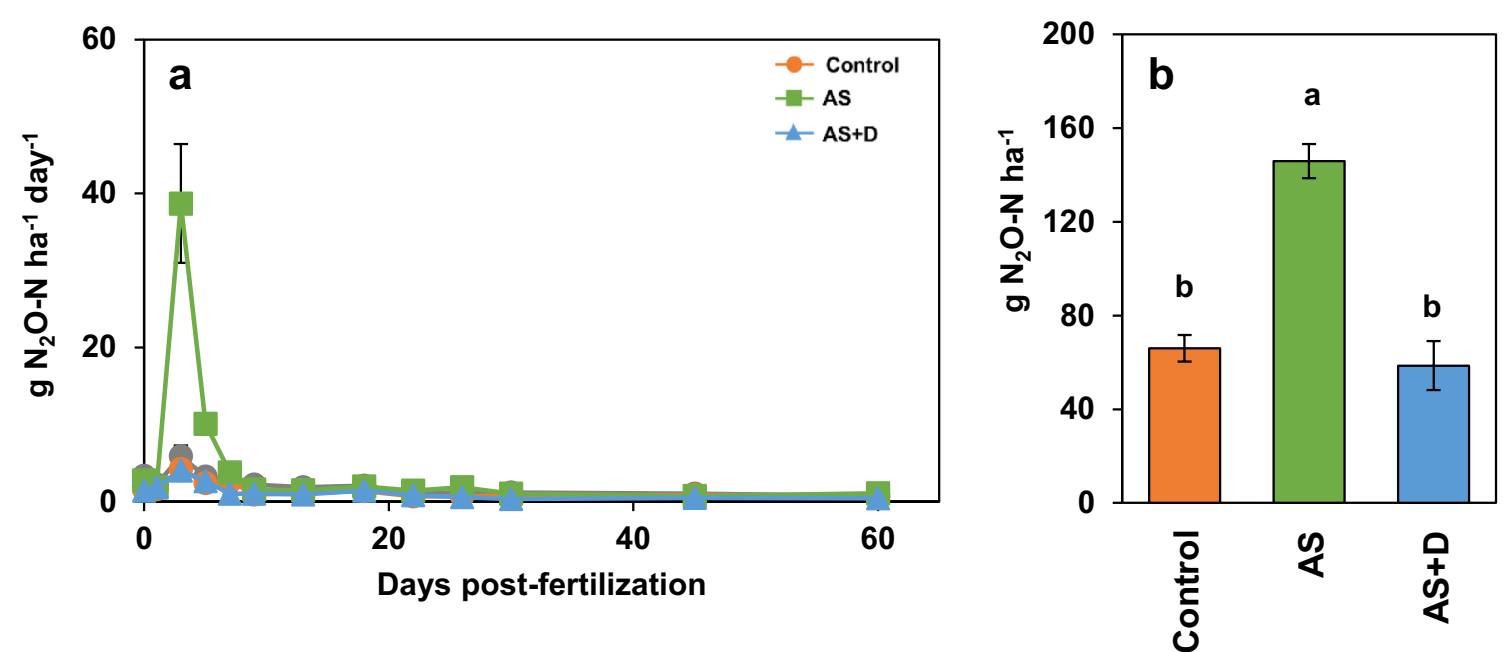

Fig. 4 Daily (a) and cumulative (b) $\mathrm{N}_{2} \mathrm{O}$ emission over 60 days post-fertilization. Control=sorghum without fertilization; $\mathrm{AS}=$ sorghum fertilized with ammonium sulfate; $A S+D=$ sorghum fertilized with ammonium sulfate + DMPP. Different letters indicate significant differences using the Duncan test $(p<0.05 ; n=4)$

are greatly influenced [45-47]. Specifically, the AOB population exhibits a strong response to $\mathrm{N}$ fertilizers [48]. Shortly after the fertilizer application, soils tend to show a large increase in $a m o A$ abundance $[39,49]$. This growth can be avoided by applying SNIs such as DMPP, and the AOB population size is maintained at the level of unfertilized soils (Fig. 1b) [50, 51]. Furthermore, the objective of BNIs is to suppress soil nitrification by decreasing the ammonia-oxidizing microorganisms' populations [52]. Interestingly, in the absence of DMPP (AS treatment) we also observed no increases in $a m o A$ abundance in soils. The lack of AOB growth may be associated with the use of glyphosate as an herbicide to terminate winter vetch crop. Several studies have examined the effect of glyphosate on soil microbiology, but the results are highly variable. While some authors described that the use of glyphosate cause negative impacts on microbial community structure [53, 54], others affirmed that glyphosate is able to increase soil microbial biomass and respiration $[55,56]$ or, at least, have no significant impact at all [57, 58]. Nevertheless, it has been reported that the application of glyphosate at higher rates than in this experiment $\left(1.5 \mathrm{~kg} \mathrm{ha}^{-1}\right)$ had no effect on AOB and AOA abundances $[59,60]$. Moreover, glyphosate is routinely applied in no-till systems from this region. Therefore, it is reasonable that we could conclude that the inhibition of $\mathrm{AOB}$ growth was due to the action of BNI molecules present in sorghum root exudates. This is the first field demonstration that sorghum can avert $\mathrm{AOB}$ growth with the same efficiency as SNIs.

Soil mineral $\mathrm{N}$ is a useful tool to monitor the activity of $\mathrm{AOB}$ based on the oxidation of $\mathrm{NH}_{4}^{+}$to $\mathrm{NO}_{3}{ }^{-}$.
The use of SNIs such as DMPP maintains soil $\mathrm{NH}_{4}{ }^{+}$for longer periods due to a delay in $\mathrm{NH}_{4}{ }^{+}$oxidation as a consequence of AOB inhibition [61]. When ammoniumbased fertilizers are applied without nitrification inhibitors, soil $\mathrm{NH}_{4}{ }^{+}$increases substantially followed by a rapid decrease and the appearance of $\mathrm{NO}_{3}{ }^{-}[62,63]$. In our work, AS treatment kept soil $\mathrm{NH}_{4}{ }^{+}$content in parallel with the AS + D treatment (Fig. 2a). This could be a consequence of BNIs released by sorghum, demonstrating the ability to maintain $\mathrm{NH}_{4}{ }^{+}$content at the same level as DMPP, which aligns with the equal AOB populations in both soils (Fig. 1b). Although $20 \%$ of total $\mathrm{N}$ losses from field-applied $\mathrm{N}$ occur through volatilization of ammonia, the great majority of $\mathrm{N}$ losses occur after microbial reactions transform $\mathrm{NH}_{4}{ }^{+}$in soils into $\mathrm{NO}_{3}{ }^{-}$[64]. Therefore, it seems that the use of BNI could be a good option to reduce soil $\mathrm{N}$ losses due to its ability to withhold $\mathrm{NH}_{4}{ }^{+}$ oxidation derived from the inhibition of AOB growth. Nonetheless, the capacity of BNIs to diminish nitrification seemed to decline over time, as suggested by the daily evolution of soil mineral N (Fig. 2a, b). Although soil $\mathrm{NH}_{4}{ }^{+}$and $\mathrm{NO}_{3}{ }^{-}$contents were equivalent between AS- and AS + D-treated soils, differences arose after 20 DPF. The $\mathrm{NO}_{3}{ }^{-} \mathrm{N} / \mathrm{NH}_{4}{ }^{+}-\mathrm{N}$ ratio under AS treatment increased relative to the $\mathrm{AS}+\mathrm{D}$ treatment (Fig. 2c), which may indicate that the efficiency of BNIs in reducing $\mathrm{NH}_{4}{ }^{+}$oxidation only lasted until $20 \mathrm{DPF}$. It would be interesting to track $\mathrm{AOB}$ abundance over time for longer in further studies to examine the effect of this possible decline in BNI activity on AOB growth. These differences in the $\mathrm{NO}_{3}{ }^{-}-\mathrm{N} / \mathrm{NH}_{4}{ }^{+}-\mathrm{N}$ ratio were also associated with an effect on sorghum leaf $\delta^{15} \mathrm{~N}$ values. The natural 
variation in the heavy $\mathrm{N}$ isotope $\left({ }^{15} \mathrm{~N}\right)$ has now being used with increasing frequency in physiological studies related to $\mathrm{N}$ metabolism [65-67]. For example, $\mathrm{N}$ fixation processes, both free and biological, tend to impoverish $\delta^{15} \mathrm{~N}$ because the value of the atmospheric $\mathrm{N}_{2}$ is zero. Thus, because the sorghum crop was sown after winter vetch, which is an $\mathrm{N}$-fixing crop, the leaf $\delta^{15} \mathrm{~N}$ values of the sorghum control treatment were below zero (Fig. 3). In addition, [66] noted that plants grown with $\mathrm{NH}_{4}{ }^{+}$as the sole source of $\mathrm{N}$ demonstrated a decrease in $\delta^{15} \mathrm{~N}$. Therefore, as suggested by [68], $\delta^{15} \mathrm{~N}$ can be used as an indicator of the origin of the main $\mathrm{N}$ source available to the plant during its development. The lower $\delta^{15} \mathrm{~N}$ values of the AS and AS +D treatments indicated that the sorghum crops were exposed to a dominating ammonium nutrition for a longer period than the control treatment. Nevertheless, at $30 \mathrm{DPF}$, the $\mathrm{NO}_{3}{ }^{-}-\mathrm{N} / \mathrm{NH}_{4}{ }^{+}-\mathrm{N}$ ratio in soils from the AS treatment showed an increase compared to the AS $+\mathrm{D}$ treatment (Fig. 2c), probably due to the aforementioned decline in BNI effectivity. This means that sorghum plants under AS had greater access to $\mathrm{NO}_{3}{ }^{-}$than sorghum under the AS+D treatment. As a consequence, the $\delta^{15} \mathrm{~N}$ values of the AS treatment were less negative than those of AS+D at 30 DPF (Fig. 3a). In addition, $\delta^{15} \mathrm{~N}$ values of the fertilized treatments did not attain the values of the control without fertilization. This indicates that while BNIs are less efficient than the synthetic inhibitor DMPP, they still promote a certain amount of plant $\mathrm{NH}_{4}{ }^{+}$nutrition.

The main process responsible for $\mathrm{N}_{2} \mathrm{O}$ production in soils is denitrification [69]. $\mathrm{N}_{2} \mathrm{O}$ emissions are related to soil water content [70], but the humid Mediterranean climate is characterized by a hot and dry summer. The threshold between water-limited and aeration-limited microbial processes is supposed to occur at soil moisture levels of $60 \%$ WFPS [70]. Therefore, since the soil WFPS of the present study did not exceed $25 \%$ most of the time (Additional file 2: Fig. S2), it is possible that denitrifiers were not responsible for $\mathrm{N}_{2} \mathrm{O}$ emissions. This may have been due to the lack of variation between treatments in the abundance of the nirK gene at 20 DPF (Fig. 1c). On the other hand, nitrifying microorganisms can also produce $\mathrm{N}_{2} \mathrm{O}$ via nitrifiers' denitrification processes [71]. Nevertheless, although nitrifying populations might have been responsible for the emission peak in the AS treatment at 3 DPF (Fig. 4a), at the same time there were no differences in AOB abundance at 20 DPF between AS and $\mathrm{AS}+\mathrm{D}$ (Fig. 1b). We hypothesized that the presence of the $\mathrm{N}_{2} \mathrm{O}$ emission peak at $3 \mathrm{DPF}$ and the inhibition of $\mathrm{AOB}$ growth at $20 \mathrm{DPF}$ is related to the amount of BNIs released by the sorghum roots. The release of BNIs is influenced by soil $\mathrm{NH}_{4}{ }^{+}$content, which at higher concentrations has been shown to stimulate greater BNI release in sorghum roots [72]. Therefore, the limited soil $\mathrm{NH}_{4}{ }^{+}$ content before the $\mathrm{N}_{2} \mathrm{O}$ measurements did not promote the release of enough BNIs to reduce nitrification in the first few days after fertilizer application. Nonetheless, $B N I$ release increased in sorghum after the addition of ammonium-based fertilizer, inhibiting $\mathrm{AOB}$ growth at 20 DPF, and this occurred despite a lack of complete inhibition of nitrification during the first 7 DPF. The fact that the $\mathrm{N}_{2} \mathrm{O}$ emission peak in the AS treatment was reduced before 7 DPF, while the $\mathrm{N}_{2} \mathrm{O}$ emission peaks of fertilized treatments without nitrification inhibitors lasted more than 15 days $[51,73]$ is in line with this hypothesis. During the rest of the experiment, sorghum exudates were able to maintain low $\mathrm{N}_{2} \mathrm{O}$ emissions similar to the $\mathrm{AS}+\mathrm{D}$ treatment, which showed great efficiency in reducing them, as described in other studies [74-76]. Nonetheless, this indicates that even though BNIs have a similar efficiency to SNIs in reducing $\mathrm{N}_{2} \mathrm{O}$ emissions, the delay in BNI release due to the absence of high soil $\mathrm{NH}_{4}{ }^{+}$content does not prevent $\mathrm{N}_{2} \mathrm{O}$ emissions in the short-term.

\section{Conclusions}

The use of allelopathic substances from plants to reduce nitrification in the soil is a topic of increasing interest. BNI inhibition could be a nature-based solution to diminish $\mathrm{N}$ losses, avoiding reliance on new technologies that are not widely adopted. BNIs from sorghum were able to prevent an increase in $a m o A$ after $\mathrm{N}$ fertilization with the same efficiency as DMPP. Moreover, total bacterial abundance was not affected by either the presence of sorghum roots exudates or by DMPP. In addition, both BNIs and SNIs maintained similar soil $\mathrm{NH}_{4}{ }^{+}$contents throughout the experiment. However, sorghum root exudates could not prevent the appearance of soil $\mathrm{NO}_{3}{ }^{-}$ after $20 \mathrm{DPF}$, which might indicate that the BNI effect decreases in efficiency after a certain amount of time. While DMPP maintained low $\mathrm{N}_{2} \mathrm{O}$ emissions throughout the experiment, the AS treatment presented one peak at 3 DPF that lasted until 7 DPF. Since the release of BNIs is related to the soil $\mathrm{NH}_{4}{ }^{+}$concentration, we hypothesize that the limited soil $\mathrm{NH}_{4}{ }^{+}$concentration before the $\mathrm{N}_{2} \mathrm{O}$ measurements did not allow release of enough BNIs to avoid this emission peak. Therefore, although sorghum root exudates can reduce nitrification in field soil, even with the same efficiency as DMPP for a certain amount of time, they are not able to prevent the $\mathrm{N}$ pollution derived from $\mathrm{N}$ fertilization as DMPP does during the entire experiment.

\section{Abbreviations}

MHPP: 3,4-Hydroxyphenyl propionate; BNI: Biological nitrification inhibitor; $\mathrm{N}$ : Nitrogen; AOB: Ammonia-oxidizing bacteria; AOA: Ammonia-oxidizing archaea; NOB: Nitrite-oxidizing bacteria; $\mathrm{N}_{2} \mathrm{O}$ : Nitrous oxide; $\mathrm{SNI}$ : Synthetic 
nitrification inhibitors; DMPP: 3,4-Dimethylpyrazole phosphate; WFPS: Waterfilled pore space.

\section{Supplementary Information}

The online version contains supplementary material available at https://doi. org/10.1186/s40538-021-00250-7.

Additional file 1: Fig S1. Precipitation (blue bars) and mean air temperature (red line) of summer growing season. Discontinue bar indicates the application of the fertilizer treatments.

Additional file 2: Fig S2. Evolution of soil temperature $(0-10 \mathrm{~cm}$ ) (red line) and soil WFPS $(0-30 \mathrm{~cm})$ (blue line) during GHG emissions measurements in sorghum crop.

\section{Acknowledgements}

Not applicable.

\section{Authors' contributions}

$\mathrm{ABL}$ conducted the experiment on the field and was the main contributor in the data processing and interpretation, also writing the manuscript. MCM participated in formal analysis, writing, reviewing and editing. LMA prepared the experimental field site, sowed the sorghum crop and participated in formal analysis, writing, reviewing and editing. PAT and CGM supervised all phases of data analysis and interpretation and reviewed the entire manuscript. All authors read and approved the final manuscript.

\section{Funding}

This project was funded by the Spanish Government (RTI2018-094623-B-C22 MCIU/AEI/FEDER, UE) and by the Basque Government (IT-932-16). Adrián Bozal-Leorri holds a Grant from the Basque Government (PRE-2020-2-0142). Mario Corrochano-Monsalve holds a Grant from the Ministry of Economy and Business of the Spanish Government (BES-2016-076725).

\section{Availability of data and materials}

Raw data used to generate the presented results are available from the corresponding author upon reasonable request.

\section{Declarations}

\section{Ethics approval and consent to participate}

Not applicable.

\section{Consent for publication}

Not applicable.

\section{Competing interests}

MCM is an associate editor of Chemical and Biological Technologies in Agriculture. The rest of the authors have no conflicts of interest to declare.

\section{Author details}

'Department of Plant Biology and Ecology, University of the Basque Country (UPV/EHU), Apdo. 644, 48080 Bilbao, Spain. ${ }^{2}$ Institute for Innovation and Sustainable Development in Food Chain (ISFOOD), Public University of Navarre, Pamplona, Spain. ${ }^{3}$ Institute for Multidisciplinary Research in Applied Biology (IMAB), Public University of Navarre, Pamplona, Spain.

Received: 14 June 2021 Accepted: 17 August 2021

Published online: 13 October 2021

\section{References}

1. Doggett H. Sorghum. Longman scientific and technical. New York: Wiley; 1988. p. 516.

2. Smith CW, Frederiksen RA, editors. Sorghum: origin, history, technology, and production, vol. 2. Hoboken: Wiley; 2000.
3. Hadebe ST, Modi AT, Mabhaudhi T. Drought tolerance and water use of cereal crops: a focus on sorghum as a food security crop in sub-Saharan Africa. J Agron Crop Sci. 2017;203:177-91. https://doi.org/10.1111/jac. 12191.

4. Dendy DAV. Sorghum and the millets: production and importance. Sorghum and Millets Chemistry and Technology. 1995;21-26.

5. Rooney LW, Waniska RD. Sorghum food and industrial utilization. In: Smith CW, Frederisken RA, editors. Sorghum: origin, history, technology, and production. New York: Wiley; 2000. p. 689-750.

6. Ciacci C, Maiuri L, Caporaso N, Bucci C, del Giudice L, Massardo DR, Pontieri P, di Fonzo N, Bean SR, loerger B, Londei M. Celiac disease: in vitro and in vivo safety and palatability of wheat-free sorghum food products. Clin Nutr. 2007:26:799-805. https://doi.org/10.1016/j.clnu.2007.05.006.

7. Taylor JR, Schober TJ, Bean SR. Novel food and non-food uses for sorghum and millets. J Cereal Sci. 2006;44:252-71. https://doi.org/10.1016/j. jcs.2006.06.009

8. Netzly DH, Butler LG. Roots of sorghum exude hydrophobic droplets containing biologically active components. Crop Sci. 1986;26:775-8. https:// doi.org/10.2135/cropsci1986.0011183X002600040031x.

9. Zakir HA, Subbarao GV, Pearse SJ, Gopalakrishnan S, Ito O, Ishikawa T, Kawano N, Nakahara K, Yoshihashi T, Ono H, Yoshida M. Detection, isolation and characterization of a root-exuded compound, methyl 3-(4-hydroxyphenyl) propionate, responsible for biological nitrification inhibition by sorghum (Sorghum bicolor). New Phytol. 2008;180:442-51. https://doi.org/10.1111/j.1469-8137.2008.02576.x.

10. Alsaadawi IS, Al-Uqaili JK, Alrubeaa AJ, Al-Hadithy SM. Allelopathic suppression of weed and nitrification by selected cultivars of Sorghum bicolor (L.) Moench. J Chem Ecol. 1985;12:209-19. https://doi.org/10.1007/BF010 45604.

11. Czarnota MA, Rimando AM, Weston LA. Evaluation of root exudates of seven sorghum accessions. J Chem Ecol. 2003;29:2073-83. https://doi. org/10.1023/A:1025634402071.

12. Nardi P, Akutsu M, Pariasca-Tanaka J, Wissuwa M. Effect of methyl 3-4-hydroxyphenyl propionate, a Sorghum root exudate, on N dynamic, potential nitrification activity and abundance of ammonia-oxidizing bacteria and archaea. Plant Soil. 2013;367:627-37. https://doi.org/10.1007/ s11104-012-1494-y.

13. Sarr PS, Ando Y, Nakamura S, Deshpande S, Subbarao GV. Sorgoleone release from sorghum roots shapes the composition of nitrifying populations, total bacteria, and archaea and determines the level of nitrification. Biol Fertil Soils. 2020;56:145-66. https://doi.org/10.1007/ s00374-019-01405-3.

14. Subbarao GV, Nakahara K, Ishikawa T, Ono H, Yoshida M, Yoshihashi T, Zhu Y, Zakir HAKM, Desphande SP, Hash CT, Sahrawat KL. Biological nitrification inhibition (BNI) activity in sorghum and its characterization. Plant Soil. 2013;366:243-59. https://doi.org/10.1007/s11104-012-1419-9.

15. Subbarao GV, Sahrawat KL, Nakahara K, Rao IM, Ishitani M, Hash CT, Kishii M, Bonnett DG, Berry WL, Lata JC. A paradigm shift towards low-nitrifying production systems: the role of biological nitrification inhibition (BNI). Ann Bot. 2013;112:297-316. https://doi.org/10.1093/aob/mcs230.

16. FAO STAT. Crops (Food and Agriculture Organization of the United Nations, 2018). http://www.fao.org/faostat/en/\#data/QC. Accessed 20 May 2021.

17. Sutton MA, Oenema O, Erisman JW, Leip A, van Grinsven H, Winiwarter W. Too much of a good thing. Nature. 2011;472:159-61. https://doi.org/10. 1038/472159a.

18. Arp DJ, Stein LY. Metabolism of inorganic N compounds by ammoniaoxidizing bacteria. Crit Rev Biochem Mol Biol. 2003;38:471-95. https://doi. org/10.1080/10409230390267446.

19. Könneke M, Bernhard AE, José R, Walker CB, Waterbury JB, Stahl DA. Isolation of an autotrophic ammonia-oxidizing marine archaeon. Nature. 2005:437:543-6. https://doi.org/10.1038/nature03911.

20. Rottenberg $\mathrm{H}$, Hashimoto K. Fatty acid uncoupling of oxidative phosphorylation in rat liver mitochondria. Biochemistry. 1986;25:1747-55.

21. Fiencke C, Spieck E, Bock E. Nitrogen fixation in agriculture. In: Forestry, ecology, and the environment. 2005;255. https://doi.org/10.1007/1-40203544-6_12

22. Hochstein LI, Tomlinson GA. The enzymes associated with denitrification. Annu Rev Microbiol. 1988;42:231-61. https://doi.org/10.1146/annurev.mi. 42.100188 .001311$.

23. IPCC (2014) Synthesis report summary chapter for policymakers. IPCC, 31. 
24. Galloway JN, Townsend AR, Erisman JW, Bekunda M, Cai Z, Freney JR, Martinelli LA, Seitzinger SP, Sutton MA. Transformation of the nitrogen cycle: recent trends, questions, and potential solutions. Science. 2008;320:88992. https://doi.org/10.1126/science.1136674.

25. Guardia G, Cangani MT, Sanz-Cobena A, Junior JL, Vallejo A. Management of pig manure to mitigate $\mathrm{NO}$ and yield-scaled $\mathrm{N}_{2} \mathrm{O}$ emissions in an irrigated Mediterranean crop. Agric Ecosyst Environ. 2017;238:55-66. https://doi.org/10.1016/j.agee.2016.09.022.

26. Torralbo F, Menéndez S, Barrena I, Estavillo JM, Marino D, González-Murua C. Dimethyl pyrazole-based nitrification inhibitors effect on nitrifying and denitrifying bacteria to mitigate $\mathrm{N}_{2} \mathrm{O}$ emission. Sci Rep. 2017;7:1-11. https://doi.org/10.1038/s41598-017-14225-y.

27. Subbarao GV, Ito O, Sahrawat KL, Berry WL, Nakahara K, Ishikawa T, Watanabe T, Suenaga K, Rondon M, Rao IM. Scope and strategies for regulation of nitrification in agricultural systems - challenges and opportunities. Crit Rev Plant Sci. 2006;25:303-35. https://doi.org/10.1080/073526806007942 32.

28. Subbarao GV, Arango J, Masahiro K, Hooper AM, Yoshihashi T, Ando Y, Nakahara K, Desphande S, Ortiz-Monasterio I, Ishitani M, Peters M, Chirinda N, Wollenberg L, Lata JC, Gerard B, Tobita S, Rao IM, Braun HJ, Kommerell V, Tohme J, Iwanaga M. Genetic mitigation strategies to tackle agricultural GHG emissions: the case for biological nitrification inhibition technology. Plant Sci. 2017;262:165-8. https://doi.org/10.1016/j.plantsci. 2017.05.004.

29. Nardi P, Laanbroek HJ, Nicol GW, Renella G, Cardinale M, Pietramellara G, Weckwerth W, Trinchera A, Ghatak A, Nannipieri P. Biological nitrification inhibition in the rhizosphere: determining interactions and impact on microbially mediated processes and potential applications. FEMS Microbiol Rev. 2020;44:874-908. https://doi.org/10.1093/femsre/fuaa037.

30. Sarr PS, Nakamura S, Ando Y, Iwasaki S, Subbarao GV. Sorgoleone production enhances mycorrhizal association and reduces soil nitrification in sorghum. Rhizosphere. 2021;17:100283. https://doi.org/10.1016/j.rhisph. 2020.100283

31. Zadoks JC, Chang TT, Konzak CF. A decimal code for the growth stages of cereals. Weed Res. 1974;14:415-21.

32. Keeny DR, Nelson DW. Inorganic forms of nitrogen. In: Black CA, editor. Methods of Soil Analysis, Part 2, American Society of Agronomy, Madison, Wisconsin, USA; 1982; p. 643-98.

33. Walkley A. Black IA. An examination of the Degtjareff method for determining soil organic matter, and a proposed modification of the chromic acid titration method. Soil Sci. 1934;37:29-38.

34. MAPA. Métodos oficiales de análisis. Tomo III. Ministerio de Agricultura, Pesca y Alimentación, Madrid. 1994

35. Watanabe FS. Olsen SR. Test of an ascorbic acid method for determining phosphorus in water and $\mathrm{NaHCO} 3$ extracts from soil. Soil Sci Society America J. 1965;29:677-8

36. Chadwick DR, Cardenas L, Misselbrook TH, Smith KA, Rees RM, Watson CJ, McGeough KL, Williams JR, Cloy JM, Thorman RE, Dhanoa MS. Optimizing chamber methods for measuring nitrous oxide emissions from plotbased agricultural experiments. Eur J Soil Sci. 2014;65:295-307. https:// doi.org/10.1111/ejss.12117.

37. Corrochano-Monsalve M, Bozal-Leorri A, Sánchez C, González-Murua C, Estavillo JM. Joint application of urease and nitrification inhibitors to diminish gaseous nitrogen losses under different tillage systems. J Clean Prod. 2021;289:125701. https://doi.org/10.1016/j.jclepro.2020.125701.

38. Linn DM, Doran JW. Effect of water-filled pore space on carbon dioxide and nitrous oxide production in tilled and nontilled soils. Soil Sci Soc Am J. 1984;48:1267-72. https://doi.org/10.2136/sssaj1984.036159950048000 $60013 x$.

39. Bozal-Leorri A, González-Murua C, Marino D, Aparicio-Tejo PM, Corrochano-Monsalve M. Assessing the efficiency of dimethylpyrazolebased nitrification inhibitors under elevated $\mathrm{CO}_{2}$ conditions. Geoderma. 2021;400:115160. https://doi.org/10.1016/j.geoderma.2021.115160.

40. Weston LA, Alsaadawi IS, Baerson SR. Sorghum allelopathy-from ecosystem to molecule. J Chem Ecol. 2013;39:142-53. https://doi.org/10.1007/ s10886-013-0245-8

41. Barrena I, Menendez S, Correa-Galeote D, Vega-Mas I, Bedmar EJ, Gonzalez-Murua C, Estavillo JM. Soil water content modulates the effect of the nitrification inhibitor 3,4-dimethylpyrazole phosphate (DMPP) on nitrifying and denitrifying bacteria. Geoderma. 2017;303:1-8. https://doi. org/10.1016/j.geoderma.2017.04.022.
42. Luchibia AO, Lam SK, Suter H, Chen Q, O'Mara B, He JZ. Effects of repeated applications of urea with DMPP on ammonia oxidizers, denitrifiers, and non-targeted microbial communities of an agricultural soil in Queensland, Australia. Appl Soil Ecol. 2020;147:103392. https://doi.org/10.1016/j. apsoil.2019.103392.

43. Corrochano-Monsalve M, González-Murua C, Estavillo JM, Estonba A, Zarraonaindia I. Unraveling DMPSA nitrification inhibitor impact on soil bacterial consortia under different tillage systems. Agric Ecosyst Environ. 2020:301:107029. https://doi.org/10.1016/j.agee.2020.107029.

44. Wang P, Chai YN, Roston R, Dayan FE, Schachtman DP. The Sorghum bicolor root exudate sorgoleone shapes bacterial communities and delays network formation. Msystems. 2021;6:e00749-20. https://doi.org/ 10.1128/mSystems.00749-20.

45. Guo JH, Liu XJ, Zhang Y, Shen JL, Han WX, Zhang WF, Christie P, Goulding KWT, Vitousek PM, Zhang FS. Significant acidification in major Chinese croplands. Science. 2010;327:1008-10. https://doi.org/10.1126/science. 1182570

46. Peng Y, Guo D, Yang Y. Global patterns of root dynamics under nitrogen enrichment. Glob Ecol Biogeogr. 2017;26:102-14. https://doi.org/10. 1111/geb.12508.

47. Zhang $M$, Wang W, Zhang $Y$, Teng $Y, X u Z$ Z. Effects of fungicide iprodione and nitrification inhibitor 3,4-dimethylpyrazole phosphate on soil enzyme and bacterial properties. Sci Total Environ. 2017;599-600:254-63. https://doi.org/10.1016/j.scitotenv.2017.05.011.

48. Ouyang Y, Evans SE, Friesen ML, Tiemann LK. Effect of nitrogen fertilization on the abundance of nitrogen cycling genes in agricultural soils: a meta-analysis of field studies. Soil Biol Biochem. 2018;127:71-8. https:// doi.org/10.1016/j.soilbio.2018.08.024.

49. Castellano-Hinojosa A, Gonzalez-Lopez J, Vallejo A, Bedmar EJ. Effect of urease and nitrification inhibitors on ammonia volatilization and abundance of $\mathrm{N}$-cycling genes in an agricultural soil. J Plant Nutr Soil Sci. 2020;183:99-109. https://doi.org/10.1002/jpln.201900038.

50. Duncan EG, O'Sullivan CA, Roper MM, Peoples MB, Treble K, Whisson K. Crop and microbial responses to the nitrification inhibitor 3,4-dimethylpyrazole phosphate (DMPP) in Mediterranean wheat-cropping systems. Soil Res. 2017;55:553-66. https://doi.org/10.1071/SR16327.

51. Nair D, Abalos D, Philippot L, Bru D, Mateo-Marín N, Petersen SO. Soil and temperature effects on nitrification and denitrification modified $\mathrm{N}_{2} \mathrm{O}$ mitigation by 3,4-dimethylpyrazole phosphate. Soil Biol Biochem. 2021;157:108224. https://doi.org/10.1016/j.soilbio.2021.108224.

52. Subbarao GV, Yoshihashi T, Worthington M, Nakahara K, Ando Y, Sahrawat KL, Rao IM, Lata JC, Kishii M, Braun HJ. Suppression of soil nitrification by plants. Plant Sci. 2015;233:155-64. https://doi.org/10.1016/j.plantsci.2015. 01.012.

53. Andréa MMD, Peres TB, Luchini LC, Bazarin S, Papini S, Matallo MB, Savoy $\mathrm{VLT}$. Influence of repeated applications of glyphosate on its persistence and soil bioactivity. Pesq Agrop Bras. 2003;38:1329-35.

54. Lancaster SH, Hollister EB, Senseman SA, Gentry TJ. Effects of repeated glyphosate applications on soil microbial community composition and the mineralization of glyphosate. Pest Manage Sci: Form Pest Sci. 2010;66:59-64. https://doi.org/10.1002/ps.1831.

55. Wardle DA, Parkinson D. Effects of three herbicides on soil microbial biomass and activity. Plant Soil. 1990;122:21-8. https://doi.org/10.1007/ BF02851906.

56. Wardle DA, Parkinson D. Influence of the herbicide glyphosate on soil microbial community structure. Plant Soil. 1990;122:29-37. https://doi. org/10.1007/BF02851907.

57. Zabaloy MC, Gómez E, Garland JL, Gómez MA. Assessment of microbial community function and structure in soil microcosms exposed to glyphosate. Appl Soil Ecol. 2012;61:333-9. https://doi.org/10.1016/j.apsoil. 2011.12.004.

58. Rosenbaum KK, Miller GL, Kremer RJ, Bradley KW. Interactions between glyphosate, Fusarium infection of common waterhemp (Amaranthus rudis), and soil microbial abundance and diversity in soil collections from Missouri. Weed Sci. 2014;62:71-82. https://doi.org/10.1614/ WS-D-13-00071.1.

59. Allegrini M, Gomez EDV, Zabaloy MC. Repeated glyphosate exposure induces shifts in nitrifying communities and metabolism of phenylpropanoids. Soil Biol Biochem. 2017;105:206-15. https://doi.org/10.1016/j.soilb io.2016.11.024. 
60. Zabaloy MC, Allegrini M, Tebbe DA, Schuster K, Gomez EDV. Nitrifying bacteria and archaea withstanding glyphosate in fertilized soil microcosms. Appl Soil Ecol. 2017;117:88-95. https://doi.org/10.1016/j.apsoil. 2017.04.012.

61. Ruser $R$, Schulz $R$. The effect of nitrification inhibitors on the nitrous oxide $\left(\mathrm{N}_{2} \mathrm{O}\right)$ release from agricultural soils - a review. J Plant Nutr Soil Sci. 2015:178:171-88. https://doi.org/10.1002/jpln.201400251.

62. Corrochano-Monsalve M, Huérfano X, Menéndez S, Torralbo F, FuertesMendizábal T, Estavillo JM, González-Murua C. Relationship between tillage management and DMPSA nitrification inhibitor efficiency. Sci Total Environ. 2020;718:134748. https://doi.org/10.1016/j.scitotenv.2019. 134748.

63. Montoya M, Vallejo A, Corrochano-Monsalve M, Aguilera E, Sanz-Cobena A, Ginés C, González-Murua C, Álvarez JM, Guardia G. Mitigation of yield-scaled nitrous oxide emissions and global warming potential in an oilseed rape crop through N source management. J Environ Manag. 2021;288:112304. https://doi.org/10.1016/j.jenvman.2021.112304.

64. Subbarao GV, Searchinger TD. Opinion: a "more ammonium solution" to mitigate nitrogen pollution and boost crop yields. Proc Natl Acad Sci. 2021. https://doi.org/10.1073/pnas.2107576118.

65. Purnell MP, Botella JR. Tobacco isoenzyme 1 of NAD(H)-dependent glutamate dehydrogenase catabolizes glutamate in vivo. Plant Physiol. 2007;143:530-9. https://doi.org/10.1104/pp.106.091330.

66. Ariz I, Cruz C, Moran JF, González-Moro MB, García-Olaverri C, GonzálezMurua C, Martins-Louçao MA, Aparicio-Tejo PM. Depletion of the heaviest stable $\mathrm{N}$ isotope is associated with $\mathrm{NH}_{4}{ }^{+} / \mathrm{NH}_{3}$ toxicity in $\mathrm{NH}_{4}{ }^{+}$-fed plants. BMC Plant Biol. 2011;11:83. https://doi.org/10.1186/1471-2229-11-83.

67. Ariz I, Boeckstaens M, Gouveia C, Martins AP, Sanz-Luque E, Fernández E, Soveral G, von Wiren N, Marini AM, Aparicio-Tejo PM, Cruz C. Nitrogen isotope signature evidences ammonium deprotonation as a common transport mechanism for the AMT-Mep-Rh protein superfamily. Sci Adv. 2018;4:eaar3599. https://doi.org/10.1126/sciadv.aar3599.

68. Werner RA, Schmidt HL. The in vivo nitrogen isotope discrimination among organic plant compounds. Phytochemistry. 2002;61:465-84. https://doi.org/10.1016/S0031-9422(02)00204-2.

69. Davidson EA, Keller M, Erickson HE, Verchot LV, Veldkamp E. Testing a conceptual model of soil emissions of nitrous and nitric oxides: using two functions based on soil nitrogen availability and soil water content, the hole-in-the-pipe model characterizes a large fraction of the observed variation of nitric oxide and nitrous oxide emissions from soils. Bioscience. 2000;50:667-80. https://doi.org/10.1641/0006-3568(2000)050[0667: TACMOS]2.0.CO;2.
70. Davidson EA. Fluxes of nitrous oxide and nitric oxide from terrestrial ecosystems. Microbial production and consumption of greenhouse gases: methane, nitrous oxide, and halomethanes. 1991;219-235.

71. Wrage N, Velthof GL, van Beusichem ML, Oenema O. Role of nitrifier denitrification in the production of nitrous oxide. Soil Biol Biochem. 2001;33:1723-32. https://doi.org/10.1016/S0038-0717(01)00096-7.

72. Subbarao GV, Sahrawat KL, Nakahara K, Ishikawa T, Kishii M, Rao IM, Hash CT, George TS, Rao PS, Nardi P, Bonnet D, Berry W, Suenaga K, Lata JC. Biological nitrification inhibition-a novel strategy to regulate nitrification in agricultural systems. Adv Agron. 2012;114:249-302. https://doi.org/10. 1016/B978-0-12-394275-3.00001-8.

73. Recio J, Vallejo A, Le-Noe J, Garnier J, García-Marco S, Álvarez JM, SanzCobena $A$. The effect of nitrification inhibitors on $\mathrm{NH}_{3}$ and $\mathrm{N}_{2} \mathrm{O}$ emissions in highly $\mathrm{N}$ fertilized irrigated Mediterranean cropping systems. Sci Total Environ. 2018;636:427-36. https://doi.org/10.1016/j.scitotenv.2018.04.294.

74. Huérfano X, Fuertes-Mendizábal T, Dunabeitia MK, González-Murua C, Estavillo JM, Menéndez S. Splitting the application of 3,4-dimethylpyrazole phosphate (DMPP): influence on greenhouse gases emissions and wheat yield and quality under humid Mediterranean conditions. Eur J Agron. 2015;64:47-57. https://doi.org/10.1016/j.eja.2014.11.008.

75. Huérfano X, Estavillo JM, Fuertes-Mendizábal T, Torralbo F, GonzálezMurua C, Menéndez S. DMPSA and DMPP equally reduce $\mathrm{N}_{2} \mathrm{O}$ emissions from a maize-ryegrass forage rotation under Atlantic climate conditions. Atmos Environ. 2018;187:255-65. https://doi.org/10.1016/j.atmosenv. 2018.05.065

76. Liu C, Liu H, Liu X, Zhang Y, Wang L, Guan D, Al-Kaisi MM, Li Z, Zhang M. Nitrification inhibitor 3,4-dimethylpyrazole phosphate (DMPP) reduces $\mathrm{N}_{2} \mathrm{O}$ emissions by altering the soil microbial community in a wheatmaize rotation on the North China Plain. Eur J Soil Sci. 2020. https://doi. org/10.1111/ejss.13017.

\section{Publisher's Note}

Springer Nature remains neutral with regard to jurisdictional claims in published maps and institutional affiliations.

\section{Submit your manuscript to a SpringerOpen ${ }^{\circ}$ journal and benefit from:}

- Convenient online submission

- Rigorous peer review

- Open access: articles freely available online

- High visibility within the field

- Retaining the copyright to your article

Submit your next manuscript at $\boldsymbol{\nabla}$ springeropen.com 